\title{
Stereochemistry of the Conversion of 2-Phenoxyethanol into Phenol and Acetaldehyde by Acetobacterium sp.
}

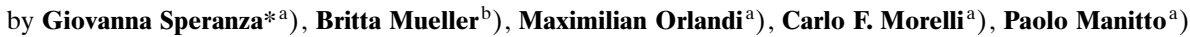 \\ and Bernhard Schink ${ }^{b}$ ) \\ a) Dipartimento di Chimica Organica e Industriale, Università degli Studi di Milano, via Venezian 21, \\ I-20133 Milano (phone: + 390250314097; fax: + 390250314072; e-mail: giovanna.speranza@unimi.it) \\ b) Fakultät für Biologie, Universität Konstanz, Universitätsstrasse 10, D-78457 Konstanz
}

The conversion of 2-phenoxyethanol to phenol and acetate by the anaerobic bacterium Acetobacterium sp. strain LuPhet1 proceeds through acetaldehyde with concomitant migration of a H-atom from $\mathrm{C}(1)$ to $\mathrm{C}(2)$ of the glycolic moiety. Separate feeding experiments with $(R)$ - and $(S)$-2-phenoxy $\left(1-{ }^{2} \mathrm{H}\right)$ ethanol, prepared via chemoenzymatic syntheses, indicate that the $\mathrm{H}$-atom involved in the 1,2 -shift is the pro-S one of the enantiotopic couple of the alcohol function.

Introduction. - Ether cleavage is particularly difficult both in vitro [1] and in vivo [2]. For microbial degradation of polyethylene glycol (PEG) molecules (1) both by aerobic [3] and anaerobic [4] bacteria, several different biochemical mechanisms have been proposed. However, the formation of a hemi-acetal structure (i.e., $\mathbf{2}$ and $\mathbf{3}$ ) as the penultimate step of the ether cleavage appears to be the predominant strategy [2] (Scheme 1).

Scheme 1. Putative Reaction Mechanisms of Microbial PEG Degradation under Aerobic (a) [3] and Anaerobic (b) $[4 \mathrm{f}]$ Conditions

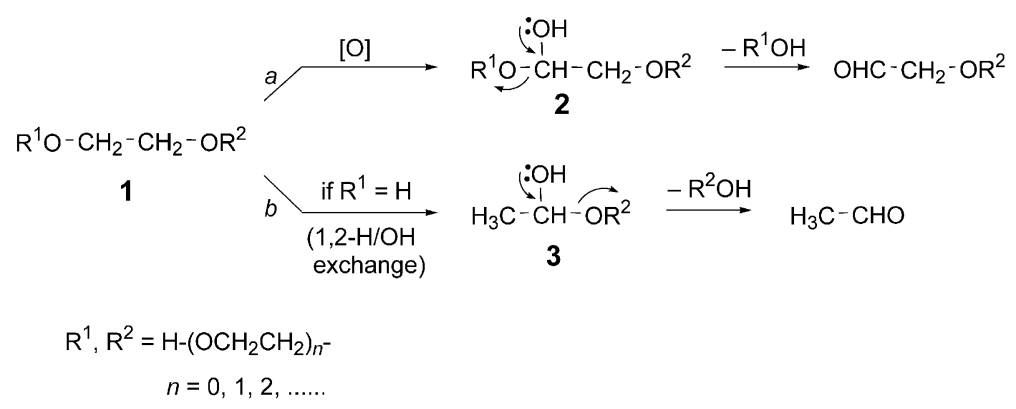

The anaerobic homoacetogenic Acetobacterium strain LuPhet1 was found to degrade low-molecular-weight PEGs, but also to convert 2-phenoxyethanol (4) via MeCHO (5) to acetate 6 with release of phenol (Scheme 2) [4f]. Thus, 4 can be regarded as a useful model compound to study the enzymatic ether cleavage of PEG.

Experiments carried out with ${ }^{2} \mathrm{H}$ - and ${ }^{13} \mathrm{C}$-labeled 2-phenoxyethanol and resting cell suspensions of strain LuPhet1 allowed us to clarify the fate of the C-and H-atoms of 4 in the reaction giving rise to $\mathrm{MeCHO}$ (isolated as $\mathrm{AcONa}$ ). As shown in Scheme 3,a,

Konstanzer Online-Publikations-System (KOPS)

URL: http://www.ub.uni-konstanz.de/kops/volltexte/2007/2712/

URN: http://nbn-resolving.de/urn:nbn:de:bsz:352-opus-27121 
Scheme 2. Stoichiometry of the Anaerobic Fermentation of 2-Phenoxyethanol by Acetobacterium sp. Strain LuPhet1

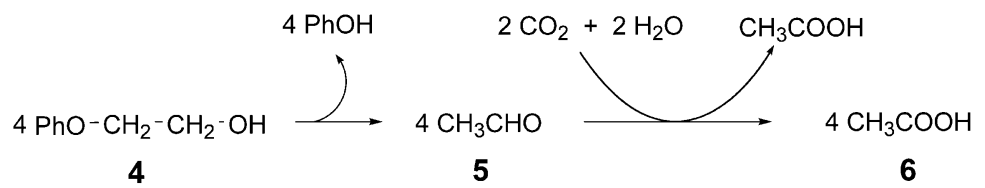

the alcohol function of 2-phenoxyethanol becomes a carboxy group, whereas the adjacent $\mathrm{CH}_{2}$ group is transformed into a Me group with concomitant intramolecular 1,2- $\mathrm{H}$ shift [5]. These findings could be interpreted in terms of 1,2-PhO shift as a route alternative to the 1,2-OH shift previously hypothesized (see path $b$ of Scheme 1, where $\mathrm{R}^{2}=\mathrm{Ph}$ ) [4f]. However, the radical mechanism depicted in Scheme 3,b [5], which does not involve a hemi-acetal as a necessary intermediate, seems more likely. It is supported by the well-recognized propensity of ketyl radicals (radical anions) to eliminate adjacent leaving groups [6] (step II in Scheme 3,b). In addition, it is consistent with a Htransfer without exchange with the medium [7], and, in this respect, it is reminiscent of diol-dehydratase-catalyzed reactions [8]. We report here the determination of a cryptostereochemical feature of the transformation of 2-phenoxyethanol (4) into $\mathrm{MeCHO}$, namely, the enantioselectivity exerted by the enzyme in the $\mathrm{H}$-abstraction from the substrate (e.g., reaction I in Scheme 3,b).

Scheme 3. a) Fate of $\mathrm{H}$ - and $\mathrm{C}$-Atoms in the Conversion of 2-Phenoxyethanol to AcOH by Strain LuPhet1. b) Hypothetical Enzymatic Mechanism for Glycol Ether Cleavage [5].

a)

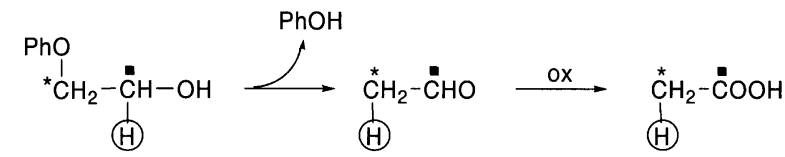

b)

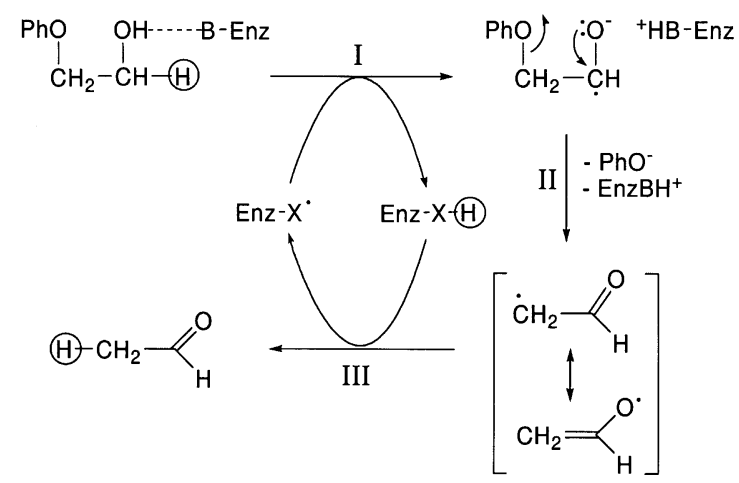


Results and Discussion. - To distinguish between the enantiotopic H-atoms of the primary alcohol group of $\mathbf{4}$, we prepared both the $C(1)$-monodeuterated enantiomers of 2-phenoxyethanol, i.e., 7 and ent-7. A substantial amount of $(S)$-2-phenoxy(1${ }^{2} \mathrm{H}$ )ethanol (7) was synthesized by baker's yeast mediated hydrogenation of the corresponding deuterated aldehyde 10, which was prepared from ethyl 2-phenoxyacetate (8) via the dideuterated alcohol $(\mathbf{9} ;$ Scheme 4$)$. The enantiomeric purity (ca. $100 \%$ ) and the D content (monodeuterated molecules $>98 \%$ ) of the alcohol resulting from the enzymatic reduction were checked by ${ }^{1} \mathrm{H}-\mathrm{NMR}$ of the Mosher ester [9] (compared with the ester of the racemic mixture, Fig. 1,a and $b$ ) and by MS measurements. The configuration of 7 was expected to be $(S)$ on the basis of the wellknown empirical rules regarding the stereoselective hydrogenation of the carbonyl group by Saccharomyces cerevisiae (baker's yeast) [10]. In any case, it was confirmed by chemical correlation of 7 with $(+)-(S)-2-($ benzyloxy $)\left(1-{ }^{2} \mathrm{H}\right)$ ethanol (13) [11] (Scheme 5). Compound $\mathbf{1 3}$ was obtained through the baker's yeast mediated reduction of the deuterated aldehyde $\mathbf{1 2}$ and was shown to be identical in all respects (including the sign and the value of optical rotation) with the compound of unequivocal configuration previously synthesized by an independent route [11]. The conversion of 13 to 7 was then achieved by exploiting the activation of the alcohol 14 with the Mitsunobu reagents [12], followed by reaction with phenol to give $\mathbf{1 5}$. The inversion of

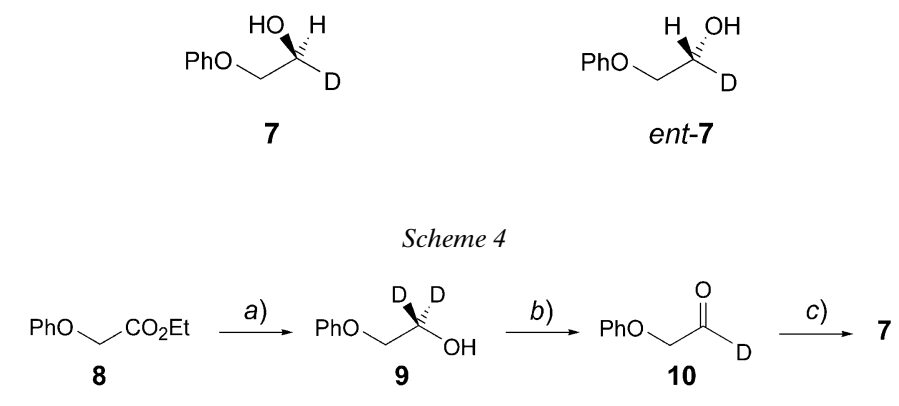

a) $\mathrm{LiAID}_{4}, \mathrm{Et}_{2} \mathrm{O}$. b) Swern oxidation. c) Bakers's yeast.

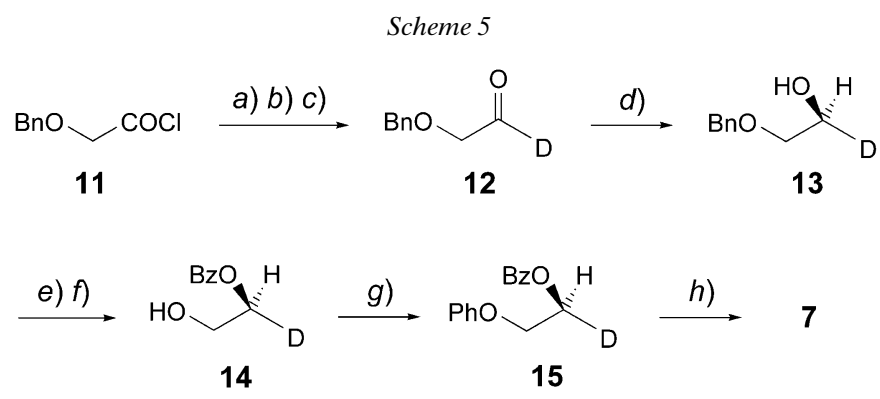

a) EtOH, $\mathrm{Py}, \mathrm{CH}_{2} \mathrm{Cl}_{2}$. b) $\mathrm{LiAID}_{4}, \mathrm{Et}_{2} \mathrm{O}$. c) Swern oxidation. d) Baker's yeast. e) $\left.\mathrm{PhCOCl}_{\mathrm{Py}} \mathrm{CH}_{2} \mathrm{Cl}_{2} . f\right) \mathrm{H}_{2}$, $10 \% \mathrm{Pd} / \mathrm{C}$, MeOH. g) $\mathrm{PPh}_{3}$, diisopropyl azodicarboxylate (DIAD), $\mathrm{PhOH}$, THF. $h$ ) $\mathrm{NaOH}, \mathrm{EtOH}$. 
a)

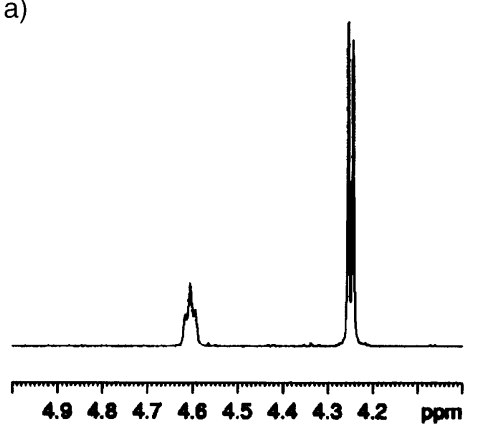

b)

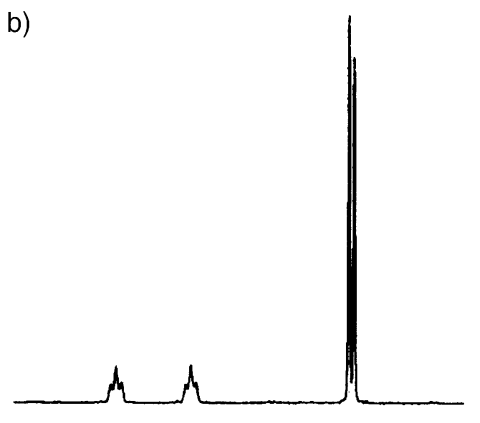

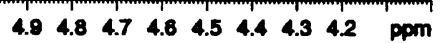

c)

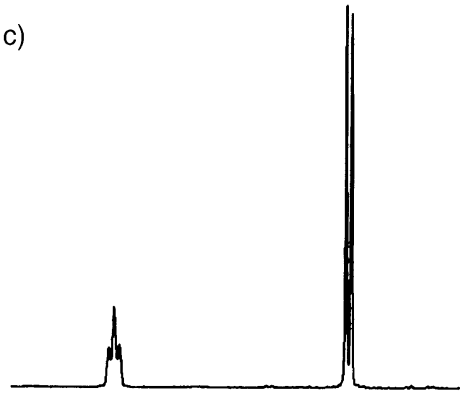

$4.94 .84 .74 .64 .54 .4 \quad 4.34 .2 \quad \mathrm{ppm}$<smiles>[2H][C@@H](COc1ccccc1)OC(=O)[C@](OC)(c1ccccc1)C(F)(F)F</smiles><smiles>[2H]C(COc1ccccc1)OC(=O)[C@](OC)(c1ccccc1)C(F)(F)F</smiles>

Fig. 1. ${ }^{1} \mathrm{H}$-NMR Signals $\left(300 \mathrm{MHz}, \mathrm{CDCl}_{3}\right)$ due to the glycolic moiety of Mosher's (R)-esters of a) (S)-2phenoxy $\left(1-{ }^{2} H\right)$ ethanol; b) rac-2-phenoxy $\left(1-{ }^{2} H\right)$ ethanol, and c) $(\mathrm{R})$-2-phenoxy $\left(1-{ }^{2} H\right)$ ethanol

the configuration at $\mathrm{C}(1)$ of $(S)$-2-phenoxy $\left(1-{ }^{2} \mathrm{H}\right)$ ethanol (7) was accomplished by means of the classical Mitsunobu procedure [12], thus providing enantiomerically pure ent-7 in good yields ( $c f$. the Mosher ester in Fig. 1,c). 

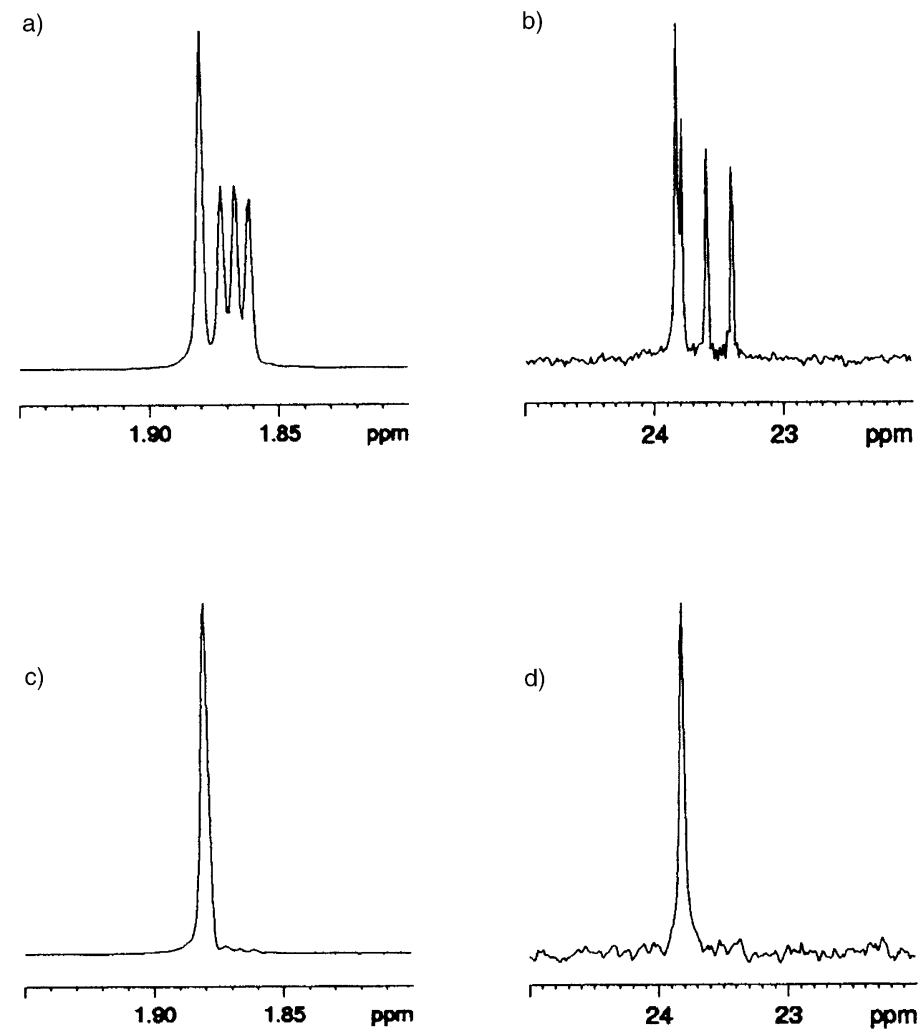

Fig. 2. ${ }^{1} \mathrm{H}$ - (400 MHz) and ${ }^{13} \mathrm{C}-\mathrm{NMR}(100 \mathrm{MHz})$ spectra of $\mathrm{AcONa}$ (in $\mathrm{NaOD} / \mathrm{D}_{2} \mathrm{O}$; Me-group resonances only) obtained by fermentation of (S)-2-phenoxy $\left(1-{ }^{2} H\right)$ ethanol $(a$ and $b)$ and $(\mathrm{R})$-2-phenoxy $\left(1-{ }^{2} H\right)$ ethanol $(c$ and $d)$. For values of coupling constants and isotope shifts, see text.

When Acetobacterium cells (strain LuPhet1) [5] were fed with (S)-2-phenoxy(1${ }^{2} \mathrm{H}$ )ethanol (7), the resulting sodium acetate was found to be a mixture of monodeuterated and nondeuterated molecules in a ratio ${ }^{1}$ ) of $c a .2 .5: 1$. In fact, the ${ }^{1} \mathrm{H}$ - and ${ }^{13} \mathrm{C}-\mathrm{NMR}$ spectra of this acetate exhibited the typical patterns of signals due to $\mathrm{CH}_{2} \mathrm{D}\left(1: 1: 1\right.$ triplet, $\left.{ }^{2} J(\mathrm{H}, \mathrm{D})=2.05 \mathrm{~Hz}\right)$ and ${ }^{13} \mathrm{CH}_{2} \mathrm{D} \quad(1: 1: 1$ triplet, $J(\mathrm{C}, \mathrm{D})=$ $19.52 \mathrm{~Hz})$. These triplets were upfield to the singlets $\left(\delta(\mathrm{H})=1.867 \mathrm{ppm},{ }^{2} \Delta \mathrm{H}(\mathrm{D})=\right.$ $13.9 \mathrm{ppb} ; \delta(\mathrm{C})=23.593 \mathrm{ppm}, \Delta \mathrm{C}(\mathrm{D})=0.235 \mathrm{ppm})$ due to the nondeuterated $\mathrm{Me}$ group (Fig. 2, $a$ and $b$ ) [5]. By contrast, the ${ }^{1} \mathrm{H}$ - and ${ }^{13} \mathrm{C}-\mathrm{NMR}$ spectra of sodium acetate obtained from fermentation of $(R)-2$-phenoxy $\left(1-{ }^{2} \mathrm{H}\right)$ ethanol (ent-7) showed only the signals of the $\mathrm{CH}_{3}$ and ${ }^{13} \mathrm{CH}_{3}$, respectively, in the Me-group region (Fig. 2,c and $d$ ). The combined results of these feeding experiments were clearly indicative of the capacity of the enzyme to discriminate between the two $\mathrm{H}$-atoms at $\mathrm{C}(1)$ of $\mathbf{4}$, with consequent

1) As calculated from the integrated peak areas in the ${ }^{1} \mathrm{H}-\mathrm{NMR}$ spectra, taking into account the number of $\mathrm{H}$-atoms in the two species. 
migration of the (pro-S) one. It can be noted that, in the acetate arising from the fermentation of $\mathbf{7}$, some nondeuterated molecules are present besides the monodeuterated ones ${ }^{1}$ ). This fact is not due to a partial exchange of the mobile $\mathrm{H}$-atom with the medium [5], but can be explained by considering that additional $\mathrm{CH}_{3} \mathrm{CO}_{2}^{-}$is produced by $\mathrm{CO}_{2}$ reduction by this homoacetogenic bacterium (cf. Scheme 2) [4f] [5].

In conclusion, the ether cleavage in the biodegradation of 2-phenoxyethanol (4) brings about the specific 1,2-shift of one of the two enantiotopic H-atoms at $\mathrm{C}(1)$, as depicted in Scheme 6.

Scheme 6. Stereospecificity of the Microbial Conversion of 2-Phenoxyethanol to AcOH and PhOH

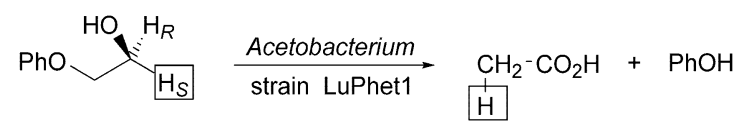

This research was supported by MIUR (Italy) and by Deutsche Forschungsgemeinschaft (Germany) in its priority program 'Radicals in Enzymatic Catalysis'.

\section{Experimental Part}

General. TLC: Silica gel $60 F_{254}$-precoated aluminum sheets (Merck); detection either by UV or spraying with a ceric sulfate/ammonium molybdate soln., followed by heating to $\mathrm{ca} .150^{\circ}$; eluent, petroleum ether/AcOEt 5 :2. Flash chromatography (FC): silica gel $(40-63 \mu \mathrm{m} ;$ Merck); eluent, petroleum ether/AcOEt $5: 2$, unless stated otherwise. GC: Dani 3850 gas chromatograph; injector, $220^{\circ}$; detector (FID), $220^{\circ}$; home-made $2 \mathrm{~m} \times$ $2 \mathrm{~mm}$ i.d. glass column, 5\% FFAP on Chromosorb W, 80-100 mesh, isothermal analysis at $200^{\circ} ; t_{\mathrm{R}}$ in $\mathrm{min}$. Optical rotations: Perkin-Elmer 241 polarimeter; 1-dm cell. NMR Spectra: Bruker AC-300 spectrometer at $300.13\left({ }^{1} \mathrm{H}\right), 46.07\left({ }^{2} \mathrm{H}\right)$, and $75.47 \mathrm{MHz}\left({ }^{13} \mathrm{C}\right)$, and Bruker Avance-400 spectrometer at $400.13\left({ }^{1} \mathrm{H}\right)$ and $100.61 \mathrm{MHz}\left({ }^{13} \mathrm{C}\right) ; \delta$ in ppm vs. solvent as internal reference $\left(\mathrm{C}(\mathrm{H}) \mathrm{DCl}_{3}: \delta(\mathrm{H} / \mathrm{D}) 7.25, \delta(\mathrm{C}) 77.00\right)$ or sodium 3(trimethylsilyl $)\left(2,2,3,3-{ }^{2} \mathrm{H}_{4}\right)$ propanoate $(\delta(\mathrm{Me})=0 \mathrm{ppm})$ in the case of $\mathrm{D}_{2} \mathrm{O} / \mathrm{NaOD}(\mathrm{pH}>10) ; J$ in $\mathrm{Hz} ;{ }^{13} \mathrm{C}$ multiplicities from APT spectra. EI-MS $(\mathrm{m} / \mathrm{z}[\%]): V G 7070 \mathrm{EQ}$ mass spectrometer; at $70 \mathrm{eV}$.

Fermentation Experiments and Isolation of Sodium Acetate. Labelled 2-phenoxyethanol samples were transformed by dense cell suspensions of Acetobacterium sp. strain LuPhet1 [5], and the produced acetate was extracted and prepared as described in [5].

Data of Sodium Acetate. ${ }^{1} \mathrm{H}-\mathrm{NMR}\left(400 \mathrm{MHz}, \mathrm{D}_{2} \mathrm{O} / \mathrm{NaOD}\right): 1.8670\left(t,{ }^{2} J(\mathrm{H}, \mathrm{D})=2.05, \mathrm{CH}_{2} \mathrm{D}\right) ; 1.8809$ $\left(s, \mathrm{CH}_{3}\right) .{ }^{13} \mathrm{C}-\mathrm{NMR}\left(100 \mathrm{MHz}, \mathrm{D}_{2} \mathrm{O} / \mathrm{NaOD}\right): 23.593\left(t, J(\mathrm{C}, \mathrm{D})=19.52, \mathrm{CH}_{2} \mathrm{D}\right) ; 23.828\left(s, \mathrm{CH}_{3}\right) ; 181.975$ $(\mathrm{COO})$.

(S)-2-Phenoxy $\left(1-{ }^{2} H\right)$ ethanol (7). A stirred soln. of oxalyl chloride $(1.7 \mathrm{ml}, 19.7 \mathrm{mmol})$ in dry $\mathrm{CH}_{2} \mathrm{Cl}_{2}$ $(60 \mathrm{ml})$ was cooled to $-80^{\circ}$ under $\mathrm{N}_{2}$ and treated dropwise with DMSO $(2.8 \mathrm{ml}, 39.4 \mathrm{mmol})$, keeping the temp. below $-65^{\circ}$. After $15 \mathrm{~min}$, a soln. of 2-phenoxy $\left(1,1-{ }^{2} \mathrm{H}_{2}\right)$ ethanol $(9 ; 1.4 \mathrm{~g}, 10 \mathrm{mmol})$, prepared from ethyl 2phenoxyacetate (8) by a published procedure [5], in dry $\mathrm{CH}_{2} \mathrm{Cl}_{2}(15 \mathrm{ml})$ was added over a period of $5 \mathrm{~min}$. Stirring was continued at $-65^{\circ}$ for $15 \mathrm{~min}$, then $\mathrm{Et}_{3} \mathrm{~N}(6.9 \mathrm{ml}, 49.5 \mathrm{mmol})$ was added dropwise with stirring. After $10 \mathrm{~min}$, the cooling bath was removed, and the mixture was stirred for $2 \mathrm{~h}$ at r.t. $\mathrm{H}_{2} \mathrm{O}(10 \mathrm{ml})$ was added, stirring was continued for $10 \mathrm{~min}$, and the two layers were separated. The aq. phase was extracted with $\mathrm{CH}_{2} \mathrm{Cl}_{2}$ $(2 \times 10 \mathrm{ml})$, and the org. layers were combined, washed two times with brine, and dried $\left(\mathrm{Na}_{2} \mathrm{SO}_{4}\right)$. Removal of the solvent under reduced pressure gave the crude 2-phenoxy $\left(1-{ }^{2} H\right)$ acetaldehyde $(\mathbf{1 0} ; 1.35 \mathrm{~g}$, quant. yield $)$ as an oil, which was used immediately in the next step. TLC: $R_{\mathrm{f}} 0.35$. GC: $t_{\mathrm{R}} 2.4$. ${ }^{1} \mathrm{H}-\mathrm{NMR}\left(300 \mathrm{MHz}, \mathrm{CDCl}_{3}\right): 4.59$ $\left(s, \mathrm{PhOCH}_{2}\right) ; 6.87-7.11$ ( $m, 3$ arom. $\left.\mathrm{H}\right) ; 7.30-7.41$ (m, 2 arom. H) $.{ }^{2} \mathrm{H}-\mathrm{NMR}\left(\mathrm{CHCl}_{3}\right): 9.89$ (br. $\left.s,{ }^{2} \mathrm{H}-\mathrm{C}(1)\right)$. Compound $10(675 \mathrm{mg}, 4.9 \mathrm{mmol})$, dissolved in $7 \mathrm{ml}$ of $\mathrm{EtOH}$, was gradually added to a suspension of baker's yeast $(500 \mathrm{~g})$ in preboiled distilled water $(500 \mathrm{ml})$, and the mixture was vigorously stirred at $37^{\circ}$ for $24 \mathrm{~h}(\mathrm{GC}$ and TLC control). The fermentation broth was saturated with $\mathrm{NaCl}$ and continuously extracted with $\mathrm{Et}_{2} \mathrm{O}$. The $\mathrm{Et}_{2} \mathrm{O}$ extract was dried $\left(\mathrm{Na}_{2} \mathrm{SO}_{4}\right)$, evaporated under reduced pressure, and purified by $\mathrm{FC}$ to give pure 7 $(400 \mathrm{mg}, 58 \%)$. TLC: $R_{\mathrm{f}}$ 0.19. GC: $t_{\mathrm{R}} 4.6 .[\alpha]_{\mathrm{D}}^{25}=+0.394\left(c=9.4, \mathrm{CHCl}_{3}\right) .{ }^{1} \mathrm{H}-\mathrm{NMR}\left(400 \mathrm{MHz}, \mathrm{CDCl}_{3}\right): 2.26(\mathrm{br}$. $s, \mathrm{OH}) ; 3.92(t t, J=4.6,1.8, \mathrm{H}-\mathrm{C}(1)) ; 4.05\left(d, J=4.6, \mathrm{CH}_{2}\right) ; 6.89-6.97$ ( $m, 3$ arom. H); $7.24-7.30$ ( $m, 2$ arom. 
$\mathrm{H}) .{ }^{2} \mathrm{H}-\mathrm{NMR}\left(\mathrm{CHCl}_{3}\right): 3.91$ (br. $\left.s,{ }^{2} \mathrm{H}-\mathrm{C}(1)\right) .{ }^{13} \mathrm{C}$ NMR $\left(100 \mathrm{MHz}, \mathrm{CDCl}_{3}\right): 61.06\left(t,{ }^{1} J(\mathrm{C}, \mathrm{D})=21.9, \mathrm{C}(1)\right) ; 69.01$ $\left(\mathrm{CH}_{2}\right) ; 114.52,121.07,129.48$ (arom. CH); 158.57 (arom. C). EI-MS: 139 (40, $\left.M^{+}\right), 122(3), 107$ (10), 94 (100); $\left({ }^{2} \mathrm{H}_{1}\right)$ species $>98 \%$. ee was found to be higher than $99 \%$ as shown by the NMR spectrum of its $(R)$-MTPA ester (see below and Fig. 1,a).

(R)-2-Phenoxy (1-2 H)ethanol (ent-7). $\mathrm{PPh}_{3}(1.65 \mathrm{~g}, 6.3 \mathrm{mmol})$, 4-nitrobenzoic acid (1.05 g, $\left.6.3 \mathrm{mmol}\right)$ and 7 (294 mg, $2.1 \mathrm{mmol}$ ) were dissolved in dry THF/toluene $1: 1(30 \mathrm{ml})$ under $\mathrm{N}_{2}$. The soln. was cooled to $-20^{\circ}$, and diisopropyl azodicarboxylate (DIAD; $1.24 \mathrm{ml}, 6.3 \mathrm{mmol}$ ) was added dropwise with stirring over a 5-min period. After $10 \mathrm{~min}$, the reaction was complete (TLC and GC analysis). Removal of the solvent under reduced pressure gave a residue, which was dissolved in hexane/AcOEt $2: 1$ and cooled to $0^{\circ}$. Insoluble material was removed by filtration, the filtrate was evaporated under reduced pressure, and the residue was purified by FC to give pure 2-phenoxy $\left(1-{ }^{2} \mathrm{H}\right)$ ethyl 4-nitrobenzoate $(505 \mathrm{mg}, 83 \%)$. TLC: $R_{\mathrm{f}} 0.49$. GC: $t_{\mathrm{R}} 5.3 .{ }^{1} \mathrm{H}-\mathrm{NMR}(300 \mathrm{MHz}$, $\left.\mathrm{CDCl}_{3}\right): 4.33\left(d, J=4.5, \mathrm{CH}_{2}\right) ; 4.69$ (br. $\left.t, J=4.5, \mathrm{H}-\mathrm{C}(1)\right) ; 6.92-7.00$ (m, 3 arom. H); $7.24-7.32$ ( $m, 2$ arom. $\mathrm{H}) ; 8.19-8.41\left(m, 4\right.$ arom. H). ${ }^{13} \mathrm{C}-\mathrm{NMR}\left(75 \mathrm{MHz}, \mathrm{CDCl}_{3}\right): 61.78\left(t,{ }^{1} \mathrm{~J}(\mathrm{C}, \mathrm{D})=22.1, \mathrm{C}(1)\right) ; 63.45\left(\mathrm{CH}_{2}\right) ; 112.49$, 121.28, 121.91, 128.62, 129.48 (arom. CH); 133.06, 148.43, 156.23 (arom. C); 162.46 (COO).

To a soln. of the above 2-phenoxy $\left(1-{ }^{2} \mathrm{H}\right)$ ethyl 4-nitrobenzoate $(500 \mathrm{mg}, 1.73 \mathrm{mmol})$ in THF $(10 \mathrm{ml})$ was added $2 \mathrm{~N} \mathrm{NaOH}(3 \mathrm{ml})$. After vigorous stirring for $2 \mathrm{~h}$ at r.t., the mixture was diluted with $\mathrm{Et}_{2} \mathrm{O}$ and $\mathrm{H}_{2} \mathrm{O}$, the two phases were separated, and the aq. layer was extracted with $\mathrm{Et}_{2} \mathrm{O}$. The combined org. extract was dried $\left(\mathrm{Na}_{2} \mathrm{SO}_{4}\right)$, concentrated, and the residue was purified by FC (petroleum ether/AcOEt 1:1) to give ent-7 $(211 \mathrm{mg}, 88 \%)$. Data as for 7, except for optical rotation: $[\alpha]_{\mathrm{D}}^{25}=-0.372\left(c=11.0, \mathrm{CHCl}_{3}\right)$. Enantiomeric purity (ee $>99 \%$ ) was checked by ${ }^{1} \mathrm{H}-\mathrm{NMR}$ spectrum of its $(R)$-MTPA ester (see below and Fig. 1,c).

rac-2-Phenoxy $\left(1-{ }^{2} H\right)$ ethanol. $\mathrm{H}_{2} \mathrm{O}(1 \mathrm{ml})$ and Amberlyst-15 $(300 \mathrm{mg})$ were added to a soln. of commercial 2-phenoxyacetaldehyde dimethyl acetal $(250 \mathrm{mg}, 1.37 \mathrm{mmol})$ in $\mathrm{MeCN}(10 \mathrm{ml})$, and the mixture was kept at r.t. under stirring. After $8 \mathrm{~h}$, the resin was filtered off, and the solvent was evaporated under reduced pressure to give crude 2-phenoxyacetaldehyde (180 mg, 96\%) [13]. TLC: $R_{\mathrm{f}} 0.35$. GC: $t_{\mathrm{R}} 2.4$. It was dissolved in EtOH $(15 \mathrm{ml})$, cooled to $0^{\circ}$ and treated portionwise with $\mathrm{NaBD}_{4}(35 \mathrm{mg}, 0.8 \mathrm{mmol})$ under stirring. The mixture was allowed to warm to r.t. and stirred for additional $2 \mathrm{~h}$. Usual workup and purification by FC (petroleum ether/ AcOEt 1:1) gave pure rac-2-phenoxy $\left(1-{ }^{2} \mathrm{H}\right)$ ethanol. Data as for 7.

Preparation of MTPA (=3,3,3-Trifluoro-2-methoxy-2-phenylpropanoic Acid) Esters. The $(R)$-MTPA esters of 7, ent-7, and rac-2-phenoxy $\left(1{ }^{2} \mathrm{H}\right)$ ethanol were prepared from commercially available $(+)-(S)-\mathrm{MTPA}-\mathrm{Cl}$ according to a published procedure [9]. Usually, $15 \mathrm{mg}$ of the alcohol was used.

(R)-MTPA Ester of 7: TLC: $R_{\mathrm{f}} 0.54 .{ }^{1} \mathrm{H}-\mathrm{NMR}\left(400 \mathrm{MHz}, \mathrm{CDCl}_{3}\right): 3.59(\mathrm{~s}, \mathrm{MeO}) ; 4.25(d, J=4.8$, $\left.\mathrm{PhOCH}_{2}\right) ; 4.61$ (br. $\left.t, J=4.8, \mathrm{CH}^{2} \mathrm{HOCO}\right) ; 6.88-6.91$ ( $m, 2$ arom. H); $7.02(t, J=7.2,1$ arom. H); $7.28-7.42$ $\left(m, 5\right.$ arom. H) ; $7.56-7.61\left(m, 2\right.$ arom. H) ${ }^{13} \mathrm{C} \mathrm{NMR}\left(100 \mathrm{MHz}, \mathrm{CDCl}_{3}\right): 55.90(\mathrm{MeO}) ; 64.42\left(t,{ }^{1} J(\mathrm{C}, \mathrm{D})=23.6\right.$, $\left.\mathrm{CH}^{2} \mathrm{HOCO}\right) ; 65.57\left(\mathrm{CH}_{2}\right) ; 115.00,121.80,127.74,128.81,129.97(\operatorname{arom} . \mathrm{CH}) ; 123.66\left(q,{ }^{1} J(\mathrm{C}, \mathrm{F})=288.9\right) ; 132.57$, 158.57 (arom. C); 166.96 (COO) (see Fig. 1,a).

(R)-MTPA Ester of ent-7: ${ }^{1} \mathrm{H}-\mathrm{NMR}\left(400 \mathrm{MHz}, \mathrm{CDCl}_{3}\right.$ ): 4.77 (br. $t, J=4.8, \mathrm{CH}^{2} \mathrm{HOCO}$ ) (see Fig. 1,c).

(R)-MTPA Ester of rac-2-Phenoxy $\left(1-{ }^{2} H\right)$ ethanol: ${ }^{1} \mathrm{H}-\mathrm{NMR}\left(300 \mathrm{MHz}, \mathrm{CDCl}_{3}\right): 4.61$ (br. $\left.t, J=4.8\right), 4.77$ (br. $t, J=4.8)\left(\mathrm{CH}^{2} \mathrm{HOCO}\right)($ see Fig. 1,b).

Preparation of (+)-(S)-2-(Benzyloxy) $\left(1-{ }^{2} H\right)$ ethanol (13). 2-(Benzyloxy) $\left(1-{ }^{2} \mathrm{H}\right)$ acetaldehyde (12) [11], prepared from commercial 2-benzyloxyacetyl chloride (11) according to published procedures [5][11], was submitted to baker's yeast reduction under the conditions described above for compound 7, giving rise to an oil, which was purified by FC to afford $\mathbf{1 3}[11]$ ( $51 \%$ overall yield) in pure form. TLC: $R_{\mathrm{f}} 0.15$. GC: $t_{\mathrm{R}} 4.8$. $[\alpha]_{\mathrm{D}}^{25}=$ $+0.301\left(c=80, \mathrm{CHCl}_{3} ;[11]:[\alpha]_{\mathrm{D}}^{20}=+0.387\right.$ (neat)). ${ }^{1} \mathrm{H}-\mathrm{NMR}:$ as in [11]. ${ }^{13} \mathrm{C}-\mathrm{NMR}\left(75 \mathrm{MHz}, \mathrm{CDCl}_{3}\right): 61.51$ $\left(t,{ }^{1} J(\mathrm{C}, \mathrm{D})=21.7, \mathrm{C}(1)\right) ; 71.40,73.30\left(2 \mathrm{CH}_{2}\right) ; 127.78,128.47$ (arom. CH); 138.00 (arom. C).

Conversion of 13 into 7 . Compound 13 was converted to $(S)$-2-benzyloxy $\left(1-{ }^{2} \mathrm{H}\right)$ ethyl benzoate in $90 \%$ yield as reported in [11]. This ester $(2.1 \mathrm{~g}, 8.2 \mathrm{mmol})$ was hydrogenated over $10 \% \mathrm{Pd} / \mathrm{C}(1 \mathrm{~g})$ in $\mathrm{MeOH}(40 \mathrm{ml})$ at r.t. for $3 \mathrm{~h}$. Filtration of the catalyst and removal of the solvent under reduced pressure gave (S)-2-hydroxy(1$\left.{ }^{2} H\right)$ ethyl benzoate $(\mathbf{1 4} ; 1.3 \mathrm{~g}, 95 \%)$. TLC: $R_{\mathrm{f}} 0.36 .{ }^{1} \mathrm{H}-\mathrm{NMR}\left(300 \mathrm{MHz}, \mathrm{CDCl}_{3}\right): 2.93$ (br. $\left.s, \mathrm{OH}\right) ; 3.88(d, J=4.7$, $\left.\mathrm{CH}_{2}\right) ; 4.37$ (br. $\left.t, J=4.7, \mathrm{H}-\mathrm{C}(1)\right) ; 7.34-7.52$ ( $m, 3$ arom. H); $7.98-8.02$ ( $m, 2$ arom. H). ${ }^{13} \mathrm{C}$ NMR $(75 \mathrm{MHz}$, $\left.\mathrm{CDCl}_{3}\right): 61.11\left(\mathrm{CH}_{2}\right) ; 66.31\left(t,{ }^{1} J(\mathrm{C}, \mathrm{D})=22.8, \mathrm{C}(1)\right) ; 128.37,129.67,133.15$ (arom. CH); 129.84 (arom. C); 167.00 (COO).

A stirred soln. of $\mathrm{PPh}_{3}(1.47 \mathrm{~g}, 5.6 \mathrm{mmol})$ and diisopropyl azodicarboxylate (DIAD; $\left.1.1 \mathrm{ml}, 5.6 \mathrm{mmol}\right)$ in THF $(60 \mathrm{ml})$ at $0^{\circ}$ was treated, sequentially, with a soln. of freshly distilled $\mathrm{PhOH}(790 \mathrm{mg}, 8.4 \mathrm{mmol})$ in THF $(4 \mathrm{ml})$ and then with a soln. of $\mathbf{1 4}(600 \mathrm{mg}, 3.6 \mathrm{mmol})$ in THF $(4 \mathrm{ml})$ over a period of $15 \mathrm{~min}$. The mixture was allowed to warm to r.t. and was stirred for an additional $1 \mathrm{~h}$ ( TLC control). After addition of $\mathrm{H}_{2} \mathrm{O}(3 \mathrm{ml})$ and a few drops of conc. $\mathrm{HCl}$, the solvent was removed under reduced pressure. The residue was dissolved in $\mathrm{Et}_{2} \mathrm{O}$ 
(40 ml), washed with $2 \mathrm{~N} \mathrm{NaOH}$ and with $\mathrm{H}_{2} \mathrm{O}$, dried $\left(\mathrm{Na}_{2} \mathrm{SO}_{4}\right)$, and concentrated to $c a$. a half volume under reduced pressure. Insoluble materials were removed by filtration, the filtrate was evaporated under reduced pressure, and the residue was purified by FC to give pure (S)-2-phenoxy $\left(1-{ }^{2} H\right)$ ethyl benzoate $(\mathbf{1 5})(600 \mathrm{mg}$, 68\%). TLC: $R_{\mathrm{f}} 0.49 .{ }^{1} \mathrm{H}-\mathrm{NMR}\left(300 \mathrm{MHz}, \mathrm{CDCl}_{3}\right): 4.31\left(d, J=4.8, \mathrm{CH}_{2}\right) ; 4.66\left(\right.$ br. $\left.t, J=4.8, \mathrm{CH}{ }^{2} \mathrm{H}\right) ; 6.95-7.01$ $\left(m, 3\right.$ arom. H); $7.25-7.59(m, 5$ arom. $\mathrm{H}) ; 8.05-8.10\left(m, 2\right.$ arom. H). ${ }^{13} \mathrm{C} \mathrm{NMR}\left(75 \mathrm{MHz}, \mathrm{CDCl}_{3}\right): 63.09$ $\left(t,{ }^{1} J(\mathrm{C}, \mathrm{D})=23.0, \mathrm{CH}^{2} \mathrm{H}\right) ; 65.97\left(\mathrm{CH}_{2}\right) ; 114.78,121.22,128.36,129.56,129.74,133.07$ (arom. $\left.\mathrm{CH}\right) ; 130.02,158.63$ (arom. C); 166.50 (COO).

$\mathrm{NaOH}$ in pellets $(2.0 \mathrm{~g})$ was added to a soln. of $\mathbf{1 5}(400 \mathrm{mg}, 1.6 \mathrm{mmol})$ in EtOH $(50 \mathrm{ml})$, and the mixture was refluxed for $1 \mathrm{~h}$. After cooling to r.t., the solvent was evaporated, and the residue was dissolved in $\mathrm{Et}_{2} \mathrm{O} / \mathrm{H}_{2} \mathrm{O}$ 1:1 (40 ml) with stirring. The two layers were separated, and the aq. phase was extracted with $\mathrm{Et}_{2} \mathrm{O}$. The org. phases were combined, dried $\left(\mathrm{Na}_{2} \mathrm{SO}_{4}\right)$, and evaporated under reduced pressure. The residue was purified by passing through a short column of silica gel (petroleum ether/AcOEt $1: 1$ ), to give $(S)$-2-phenoxy $\left(1-{ }^{2} \mathrm{H}\right)$ ethanol ( $210 \mathrm{mg}, 92 \%$ ), which was found to be identical to 7 according to the ${ }^{1} \mathrm{H}$ - and ${ }^{13} \mathrm{C}-\mathrm{NMR}$, MS, and optical rotation data.

\section{REFERENCES}

[1] F. A. Carey, R. J. Sundberg, 'Advanced Organic Chemistry', 3rd edn., Plenum Press, New York, 1990, Part B, p. $141-144$.

[2] G. F. White, N. J. Russel, E. C. Tidswell, Microbiol. Rev. 1996, 60, 216.

[3] D. P. Cox, Adv. Appl. Microbiol. 1978, 23, 173; B. A. Pearce, M. T. Heydeman, J. Gen. Microbiol. 1980, 118 , 21; J. Thélu, L. Medina, J. Pelmont, FEMS Microbiol. Lett. 1980, 8, 187; F. Kawai, Crit. Rev. Biotechnol. 1987, 6, 273; N. Obradors, J. Aguilar, Appl. Environ. Microbiol. 1991, 57, 2383.

[4] a) B. Schink, M. Stieb, Appl. Environ. Microbiol. 1983, 45, 1905; b) D. Dwyer, J. M. Tiedje, Appl. Environ. Microbiol. 1983, 46, 185; c) M. A. Grant, W. J. Payne, Biotechnol. Bioeng. 1983, 25, 627; d) S. Wagener, B. Schink, Appl. Environ. Microbiol. 1988, 54, 561; e) E. Schramm, B. Schink, Biodegradation 1991, 2, 71; f) J. Frings, B. Schink, Arch. Microbiol. 1994, 162, 199.

[5] G. Speranza, B. Mueller, M. Orlandi, C. F. Morelli, P. Manitto, B. Schink, J. Biol. Chem. 2002, $277,11684$.

[6] W. Buckel, B. T. Golding, FEMS Microbiol. Rev. 1999, 22, 523.

[7] P. A. Frey, Chem. Rev. 1990, 90, 1343.

[8] D. M. Smith, B. T. Golding, L. Radom, J. Am. Chem. Soc. 2001, 123, 1664 and refs. cit. therein.

[9] J. A. Dale, H. S. Mosher, J. Am. Chem. Soc. 1973, 95, 512.

[10] K. Faber, 'Biotransformations in Organic Chemistry', Springer-Verlag, Berlin, 1992.

[11] F. Hammerschmidt, Liebigs Ann. Chem. 1988, 955.

[12] D. L. Hughes, in 'Organic Reactions', Ed. L. A. Paquette, John Wiley, New York, 1992, Vol. 42, p. 335.

[13] J. Brussee, W. T. Loos, C. G. Kruse, A. van der Gen, Tetrahedron 1990, 46, 979. 